\title{
Kurdish Women in Rojava: From Resistance to Reconstruction
}

\author{
Pinar Tank \\ Peace Research Institute Oslo (PRIO), Norway \\ pinar@prio.no
}

\begin{abstract}
In 2010, the imprisoned leader of the Kurdistan Workers' Party (Partiya Karkeren Kurdistan, РКK), Abdullah Öcalan, declared, "The freedom of the Kurdish people can be viewed as inseparably bound to women's freedom."' This statement emphasizes a core tenet in the reinvention of the PKK's ideology as articulated by Öcalan: the understanding that freedom can only be achieved through the defeat of the patriarchal system. The women of the PKK and its sister organization, the Democratic Union Party (Partiya Yekitiya Demokrat, PYD), represent the embodiment of the PKK's new ideology, attracting international attention following Kurdish efforts to establish an autonomous region of governance in north-east Syria. This article focuses on a case study of the PYD's Syrian Kurdish Women's Protection Units (Yekineyên Parastina Jin, YPJ), and their defence of Kurdish-dominated enclaves in Syria. The analysis demonstrates the agency behind their engagement and the ideology that motivates their resistance to patriarchy in the Middle East. In so doing, the article compares the YPJ's understanding of agency to media representations of YPJ fighters' engagement, in an effort to see beyond the traditional victim/peacemaker articulation of gendered engagement, arguing instead for the need to recognize the politics behind Kurdish women's participation as combatants in the Syrian civil war.
\end{abstract}

\section{Keywords}

Kurdish female fighters - ideology of Partiya Karkeren Kurdistan (PKK) - Gender and agency - Yekîneyên Parastina Jin (YPJ) - Rojava - media framing

1 Abdullah Öcalan, "The Revolution is Female", 9 March 2010, in "Abdullah Öcalan's writings in 'Il Manifesto" < http://www.freedom-for-ocalan.com/english/hintergrund/schriften/ilmani festo.htm>. 


\section{Introduction}

In the aftermath of the Arab Uprisings, women who had been active during the demonstrations that resulted in the downfall of repressive governments in the region did not see their demands for liberation fulfilled. To the contrary, the empowerment of conservative religious voices, such as the Muslim Brotherhood in Egypt and the National Transitional Council in Libya, raised questions regarding women's rights and opportunities for participation in the public sphere. ${ }^{2}$ In Turkey, a country that had long been regarded as a model for the Middle East, the gender policies of the conservative Justice and Development Party (Adalet ve Kalkınma Partisi, AKP), resulted in demonstrations by feminists at the Gezi Park protests in 2013. Women in the region who had expected to achieve a better position as a result of their contributions in the Uprisings were disappointed to find their positions unchanged and, in many cases, their gains reversed. Feminist scholars feared that women were "the losers of the Arab Spring."3

This contrasts with the case of the Kurdish women fighting Daesh ${ }^{4}$ in Iraq and Syria. In fact, their militant resistance to state-led oppression precedes the fallout from the Arab Uprisings and the rise of Daesh. However, it was not until the siege of Kobanî in September 2014 that international media began reporting on Kurdish female fighters engaged in the battle against Daesh. This article suggests that the media's portrayal of women combatants often ignores a deeper understanding of the women's political motivations and their roots within the Kurdish movement, understood here through their commitment to revolu-

2 Isobel Coleman, "Women and the Arab Revolts", Brown Journal of International Affairs 18, no.1 (2011), 197-210. As an example of the regression in gender rights, polygamy became legal again in Libya in 2013 at the instigation of the National Transitional Council. See: Mustafa Fetouri, "Women face setbacks in new Libya", Al-Monitor Pulse, 23 March 2015 <http://www.al-monitor. com/pulse/originals/2015/03/libya-women-murder-situation-gaddafi-regime-militias. html\#ixzz4VMEvBSS5>.

3 Despite the rise of conservative governments in the region, the Arab Uprisings brought about a shift in women's public participation in discussions of the political future. As a result, Haleh Esfandiari, director of the Middle East Program at the Woodrow Wilson Center noted that women would no longer accept a "nominal role" in the future of their countries. Haleh Esfanidari, “Are Women the losers of the Arab Spring?", in Women after the Arab Awakening (Washington, DC.: Woodrow Wilson Occasional Paper series, 2012) <https://www.wilsoncen ter.org/sites/default/files/women_after_the_arab_awakening_o.pdf $>$.

4 Daesh is the Arabic acronym for "The Islamic State in Iraq and the Levant (or the Sham)", also known as ISIS or ISIL. Following its capture of Mosul in mid-2014, Daesh renamed itself as "The Islamic State". However, the terms Daesh, ISIs, and IsIL are still widely used to refer to the organization. 
tionary governance in north-east Syria. ${ }^{5}$ Thus the analysis goes beyond the media's representations in asking how the movement's ideology is reflected in Kurdish women's participation in the Syrian conflict and the obstacles in the path from resistance to reconstruction.

The article begins by addressing the issue of the mainstream media's framing of Kurdish women's militant activism, noting the absence of discussions of their ideology and, as a consequence, its limited understanding of women's political agency. The article then turns to a historical overview of women's role in the Turkish Kurdistan Workers' Party (Partiya Karkeren Kurdistan, PKK), whose ideology is the source of the Syrian Democratic Union Party's (Partiya Yekitiya Demokrat, PYD) political project. The article compares the Kurdish case with theories of recruitment and motivation for militant action from other cases of female combatants. It then analyses the ideological shift in the PKK from Marxist-Leninism towards democratic confederalism and its gender dimensions. Finally, the article illustrates the complexity of this particular case, in which the political aims are enacted in the Kurdish-controlled Rojava region of north-east Syria, given that the struggle to defend the area continues.

\section{Media Images of Kurdish Female Combatants}

At the end of December 2014, the American cable news network CNN named the Kurdish female fighters (Yekineyên Parastina Jin, YPJ) of the People's Protection Units (Yekineyên Parastina Gel, YPG) as the most inspiring women of the year. ${ }^{6}$ Their resistance to the forces of Daesh and, in particular, their resolute stand in the fight for Kobanî, the central canton in the northern Syrian region of Rojava, garnered global media attention. As an example, an informal Google search in English on the words "Kurdish female fighters" for the dates 15 March 2011 (the start of the Syrian civil war) until 31 December 2013, a period of 33 months, yields 5,230 hits. The same Google search conducted from 1 January 2014 to 1 May 2015, a period of 16 months, results in 27,500 hits. ${ }^{7}$

Despite a rising interest in Kurdish female fighters, few reports in Englishlanguage mainstream media investigate these fighters' political agency. Instead, media reports frame Kurdish women's participation in particular ways that speak to preconceived notions of femininity, centred on frailty and victimhood (as will be elaborated below). Feminist scholars point out that the

5 "Revolutionary" is used here to denote both a form of governance that results from revolution, begun with the Arab Uprisings, and one that breaks with traditional understandings of the nation-state.

6 They were awarded this honour along with a Kurdish Yazidi parliamentarian, Vian Dakhil.

7 Interest continued to augment in 2015-16. A search for the same keyword for the first half of 2016 (1 January-31 June 2016) yielded 34,500 hits, an increase of almost 12 per cent from 29,700 for the preceding six months (1 July-31 December 2015). 
characteristics of Western culture associated with femininity include weakness, interdependence, emotion, sensuality, domesticity, and the private, while those associated with masculinity include strength, autonomy, rationality, power, agression, and the public. ${ }^{8}$ In one of the foundational texts on gender and war, Jean Bethke Elshtain analyses the myth of men as "Just Warriors" and women as "Beautiful Souls", illustrating to what extent these myths define women's social position as non-combatants and men's identity as warriors. ${ }^{9}$ Other feminist scholars focus on the symbolic value attributed to women as bearers of national identity ${ }^{10}$ and thus in need of protection, while men are defenders of the "motherland" and its borders, culture, and norms. ${ }^{11}$ Scholars who discuss representations of women and men in war point out how the gendered delineation of duties makes women the passive "objectification of national and ethnic ideals" and the representatives of cultural traditions and norms, whereas men are the defenders, endowed with the power of agency to protect what women and the nation represent. ${ }^{12}$ They argue that since women constitute the collective "other" juxtaposed against the male warrior, the roles of nurturer and warrior are generally portrayed to be mutually exclusive. In fact, women as actors in war and peace were largely disregarded until the mid1990s, after which scholars and practitioners of international relations began to address the relationship between gender and security. However, to the

See: J. Ann Tickner, Gender in International Relations (New York: Columbia University Press, 1992); Laura Sjoberg and Caron Gentry, Mothers, Monsters, Whores: Women's Violence in Global Politics (London: Zed Books, 2007).

9 Jean Bethke Elshtain, Women and War (Chicago, IL: University of Chicago Press, 1995).

10 The use of the term "national identity" in social science is problematic because it loses precision when applied collectively. However, rather than simply eschewing the term altogether, I have chosen to use it in this specific context, being cognizant of the fluid and ever-changing content that this term may have. "Identity" is very much a part of the discourse of modern nationhood, all the more so in the context of aspiring nations such as the Kurds. In fact, one of Öcalan's inspirations is Benedict Anderson's “imagined communities". And as historian David McDowall has pointed out in his writings on Kurdish history, the nation-builder's key role is to persuade members of the ethnic group to subordinate individual loyalties (religious, social) to the primacy of ethnic identity during the nation-building process. David McDowall, A Modern History of the Kurds (London: I.B. Tauris, 2004), 5 .

11 Joane Nagel, "Masculinity and Nationalism: Gender and Sexuality in the Making of Nations", Ethnic and Racial Studies 21, no.2 (1998), 242-69, doi:10.1080/014198798330007; Nira Yuval-Davis, "Gender and nation", Ethnic and Racial Studies 16, no.4 (1993), 621-32, doi :10.1080/01419870.1993.9993800; Nira Yuval-Davis and Floya Anthias, eds., Woman-NationState, (London: Macmillan, 1989).

12 Nazand Bagikhani, "Kurdish Women and National Identity". Paper presented at the Middle East Studies Association, October 2001. Retrieved from <http://www.scribd.com/ doc/55014170/Kurdish-Women-and-National-Identity>. 
extent that women's involvement in matters of war and peace was visible, women were essentially attributed the roles of either peacemakers or victims. This dichotomy - victim or peacemaker - diminishes the analytical space for recognizing other forms of gendered political engagement. By seeing women (and men, by contrast) in essentialist terms, the way in which female combatants frame their own agency remains insufficiently examined. Instead, media representations reinforce the socially constructed understanding of women within a patriarchal social order as non-combatants and victims of conflict. Based on this reading, the struggle of Kurdish YPJ fighters can only be understood within the limits of gendered resistance and not as a larger political project of reconstruction.

Media framing is defined as "the process of culling a few elements of perceived reality and assembling a narrative that highlights connections among them to promote a particular interpretation."13 This substantiates what has been described as "ideologically grounded, prevailing socio-political relationships and viewpoints." ${ }^{14}$ In this case, the narrative reaffirms media perceptions of the oppressed women whose motivation for joining a political movement is described primarily in liberatory terms. This is illustrated in the CNN headline from 2008, "We won't stand for male dominance", which had the following subscript: "Female fighters in Iraq say their struggle with Turkey is more about women's rights." 15

Likewise, reports from key international news outlets prior to 2014 focus on female combatants as an anomaly to established understandings of Middle Eastern women as victims of gender oppression. As Ghanim notes, "Regarding women as perpetual victims tends to reinforce and legitimize the patriarchal premise that women are weak creatures by nature. (...) But the nature and structure of patriarchal gender relations prevents women from taking on a more constructive role in society." ${ }^{16}$ Media replications of the representation of female combatants joining the Kurdish struggle for emancipatory motives alone reinforce the stereotypes of victimhood and depreciate female fighters' political agency. Ironically, by presenting the actions of Kurdish female combatants as extraordinary, the media's fascination with them speaks to

13 Robert M. Entman, "Framing Bias: Media in the Distribution of Power", Journal of Communication 57, no.1 (2007), 163-73, on 164, doi:10.1111/j.1460-2466.2006.00336.x.

14 Jacob Groshek, "Coverage of the pre-Iraq War debate as a case study of frame indexing", Media, War \& Conflict 1, no.3 (2008), 315-88, on 316, doi:10.1177/1750635208097049.

15 Arwa Damon, "We won't stand for male dominance", $c N N, 6$ October $2008<$ http://edition. cnn.com/2008/WORLD/meast/10/o6/iraq.pkk/index.html?eref=onion $>$.

16 David Ghanim, Gender and Violence in the Middle East (Westport, C.T.: Præger Publishers, 2009), 114 . 
preconceived notions of Kurdish women as passive victims. This is also the case in other reports of Middle Eastern women in conflict. Sedghi illustrates this by referring to a story in the Washington Post on the rape of Kuwaiti women "liberated" by Iraqi soldiers, in which the focus of the report is on the cultural norms of gender oppression rather than international conflict setting, denying women agency and sustaining the narrative of Third World women as victims. ${ }^{17}$

In another example, from 2003, a journalist from the British newspaper The Guardian interviewing Kurdish peshmerga women introduces the female fighters as follows: "High in Iraq's Qandil mountains, 5,000 armed women stand ready to go into battle for liberation and sexual equality." 18 He then continues with a detailed description of a PKK fighter, focusing on her small, delicate physique ("five foot nothing in her trainers with hair pulled into a ponytail that reaches the small of her back and a multicolored thread round one slim wrist") and contrasting this with the violence she has engaged in. ${ }^{19}$ The journalist consistently elaborates on the perceived disparity between her femininity and her combat role ("one hand on her gun and the other fiddling with the scrunchy in her hair"). ${ }^{20}$

The fascination with the physical aspects of Kurdish women combatants parallels Nacos's research on how the media frames female Palestinian terrorists. ${ }^{21}$ She identifies six separate (if at times overlapping) frames commonly used in the coverage of women terrorists:

Hamideh Sedghi, "Third World Feminist Perspectives on Politics", in Women, Gender and World Politics: Perspectives, Policies and Prospects, eds. Peter R. Beckman and Francine D'Amico (Westport, Conn: Bergin \& Garvey, 1994), 89-9o. Jason Burke, "Daughters of the Revolution", The Guardian, Dispatches, 11 May $2003<\mathrm{http}: / /$ www.theguardian.com/theobserver/2003/may/11/features.magazine27>.

19 Ibid.

20 In the interview with the PKK militants - a man and a woman - the journalist is criticized by the woman when she asks "Why are you asking me social questions and asking my [male] comrade political questions?" Ibid.

See Brigitte L. Nacos, "The Portrayal of Female Terrorists in the Media: Similar Framing Patterns in the News Coverage of Women in Politics and in Terrorism", Studies in Conflict and Terrorism 28, no.5 (2005), 435-51, doi:10.1080/10576100500180352. It also corresponds to the framing of gender in the media in general. For example, women political candidates' appearance, family status, domestic arrangements, and personal lives elicit as much interest as their politics. Dianne G. Bystrom, Terry A. Robertson, \& Mary Christine Banwart, "Framing the fight: An analysis of media coverage of female and male candidates in primary races for governor and U.S. Senate in 2000", American Behavioral Scientist, 44, no.12 (2001), 1999-2013, doi:10.1177/00027640121958456; Erika Falk, Women for President: Media Bias in Nine Campaigns, (Chicago: University of Illinois Press, 2010); Kim 
1. the physical appearance frame;

2. the family connection frame;

3. the 'terrorist for the sake of love' frame;

4. the women's lib/equality frame;

5. the 'tough-as-males / tougher-than-men' frame; and

6. the 'bored, naïve, out-of-touch- with-reality' frame. ${ }^{22}$

None of these categorizations adequately reflects women's agency from a political or ideological vantage point. As illustrated below, these categorizations are likewise relevant in the case of Kurdish female fighters.

Beyond the points that emphasize physical appearance and women's equality, Kurdish female fighters are also primarily described as part of their family connections, through personal stories of hardship endured as an explanatory factor in their decision to take up arms for the Kurdish cause. The following story illustrates this: nineteen-year-old Syrian Kurd, Shireen Taher, loses her mentor, a female PKK fighter, and decides to join the YPG/YPJ. ${ }^{23}$ When her father dies in a car bomb explosion soon after, she pronounces: "I always thought that one day my father would be named as the father of martyrs, but I never thought that I would become the daughter of a martyr." As her brother notes, "Our father's death gave Shireen an enormous jolt to adhere to his will and be an outstanding fighter." 24 In this narrative, Shireen's agency is understood as emanating from her personal trauma, followed by a desire to avenge her family by joining the struggle, and in so doing, also defending the larger "family unit" of the YPG. Trauma can be a primary motivation for recruits to militant organizations, but as Spekhard and Akhmedova point out, writing about the particular case of the separatist Chechen Black Widows, "trauma alone, however, would not have motivated them into terrorism: it had to be coupled with a terror promoting ideology espoused by an organization able to equip the women to act." 25

Fridkin Kahn. The Political Consequences of Being a Woman: How Stereotypes Influence the Conduct and Consequences of Political Campaigns (New York: Columbia University Press, 1996).

22 Nacos, "The Portrayal of Female Terrorists in the Media".

23 The YPJ are the female brigade of the People's Protection Units (YPG).

24 Shireen Taher, “We are so proud' - the women who died defending Kobani against Isis", Guardian online, 30 January 2015 <https://www.theguardian.com/world/2015/jan/30/ kurdish-women-died-kobani-isis-syria >. Of the four portraits of Kurdish female combatants, only one combatant is described as motivated clearly by a political agenda. The other three are motivated by their personal histories.

Anne Speckhard and Khapta Akhmedova, "Black widows: The Chechen female suicide 
In sum, media framing "exceptionalizes" the Kurdish female fighter with its focus on her resistance to gender and state oppression. As the struggle of many Kurdish women is also within the traditional patriarchal structures of Kurdish society, this representation of reality is not entirely incorrect. Many Kurdish women in Syria and Turkey have witnessed honour killings, child or forced marriage, domestic violence, and rape culture. As Kurdish activist and writer Dirik explains, "the women's fight against ISIS is not only militarily, but also philosophically, an existential one. They not only resist against feminicidal ISIS, but also the patriarchy and rape culture prevalent among their own community." 26 However, seen from a liberatory perspective, through which the media portrays women as victims, the combatants' political agency remains centred solely on resistance, either to traditional culture or to assimilation into the respective states, Turkey and Syria. With regards to the Turkish case, the implication is that should Turkey satisfy the criteria of a multi-ethnic state, this would in itself be sufficient for Kurdish militants to abandon their political struggle. This, in essence, reduces female (and male) Kurdish militants' political project solely to a form of resistance rather than to an ideal of reconstruction.

Beyond resistance, ideology has played an equally important role in drawing Kurdish women to the YPJ and sustaining their engagement. As Nisrîn Abdullah, a YPJ commander and spokesperson, elaborates,

The YPJ is not just an army - you have to see it in its wider context. Of course it is a defence force, but it is also a social movement with its ideologies and philosophies. If we didn't have these ideas, we wouldn't have been able to make the revolution as it is now. That is why we don't see ourselves as just soldiers. ${ }^{27}$

Ideology is understood in this context as "a system of ideas and ideals, especially one that forms the basis of economic or political theory and policy" - in

terrorists", in Female suicide bombers: Dying for equality, ed. Yoram Schweitzer (Tel Aviv University: Jaffee Center for Strategic Studies (JCSS), 2006), 63-80, 75 .

26 Dilar Dirik, “The Women's Revolution in Rojava: Defeating Fascism by Constructing an Alternative Society", in A Small Key Can Open A Large Door: The Rojava Revolution, eds. Strangers in a Tangled Wilderness, (London: Combustion Books, 2015) <https://www.aca demia.edu/11963676/The_Women_s_Revolution_in_Rojava_Defeating_Fascism_by_Con structing_an_Alternative_Society>.

27 Cited in "We don't fight for death...we fight for life.' An Interview with YPJ Commander Nisrîn Abdullah", Plan C website, 17 May 2016 <http://www.weareplanc.org/blog/we-dontfight-for-death-we-fight-for-life-an-interview-with-ypj-commander-nisrin-abdullah/>. 
short, a proactive vision of a better society, as Kurdish revolutionaries perceive it. ${ }^{28}$ It is the process of producing meaning and value in social life through which social actors understand their world and act upon it. ${ }^{29}$ Resistance is therefore presented as a means to an end, not the end itself, which is the execution of the movement's ideology. Appreciating the attraction of an ideology that promises a better future necessitates an understanding of what Kurdish rebels see as past oppression.

\section{Overview of the Kurdish Movement in Turkey and Syria}

The Kurds are the world's largest stateless nation, and Turkey is the state that has the largest Kurdish population within its borders - 14.5 million, almost 20 per cent of the population. ${ }^{30}$ In Syria, the Kurdish population is estimated to be 2.2 million, although reporting bias by authorities or the Kurds themselves, and the porous nature of the border with Turkey, as well as displacement resulting from the Syrian civil war, make this figure imprecise. ${ }^{31}$ Until the 1990s, Turkey enforced bans on the use of the Kurdish language, on Kurdish cultural expression, and on the use of Kurdish place names, and denied the existence of a distinct Kurdish minority, preferring instead to refer to them as "Mountain Turks." 32 Similar efforts to assimilate the Kurdish identity occurred in Syria. Despite being Syrian citizens and the country's largest ethnic minority, many were made "stateless" and denied Syrian citizenship through a 1962 law (Decree 93) which defined 120,000 Kurds as ajānib (foreigners) who could not vote, own property, or work in government jobs. ${ }^{33}$ Another 75,000 Syrian Kurds were defined as maktümin (concealed) and enjoyed even fewer rights than the ajānib. The UN High Commission for Human Rights declared that the resulting ethnic discrimination and persecution completely deprived them of "their national, democratic and human rights." 34

28 Oxford English Dictionary, s.v. "Ideology" < https://en.oxforddictionaries.com/definition/ ideology>.

29 Terry Eagleton, Ideology: An Introduction (London: Verso, 1991), 1-2.

30 Central Intelligence Agency, World Factbook: Turkey, accessed 26 December $2016<\mathrm{https} / / /$ www.cia.gov/library/publications/the-world-factbook/geos/tu.html>. However, figures vary due to assimilation in their respective states and a rediscovery of their ethnicity during periods of state repression. David McDowall, A Modern History of the Kurds (London and New York: I.B. Tauris Publishers, 2000), 3.

Michael M. Gunter, Out of Nowhere: The Kurds of Syria in Peace and War (London: Hurst \& Company, 2014), 2.

32 Donald McDowall, The Kurds: A nation denied (London: Minority Rights Publications, 1992,4.

This status was inherited, making the number of ajānib as high as 300,000. Gunter, Out of Nowhere, 2.

United Nations High Commission for Human Rights, Persecution and Discrimina- 
The Turkish state's repression of Kurdish rebellion since the establishment of the Kemalist state in 1923 has contributed to defining women's sociopolitical role in Kurdish society. The persecution and bloody suppression of major Kurdish uprisings started with the Sheikh Said Rebellion (1925) and continued with the Ararat Revolt (1930) and the Dersim Revolt (1937-38). By 1978, a growing urban proletariat and a Turkish leftist movement set the stage for the rise of the PKK as a militant nationalist liberation front, defined by a Marxist-Leninist ideology and guided by its charismatic leader, Abdullah Öcalan. Turkey's military coup in 1980 was a catalyst, as state torture in prisons - of both ethnic Turks and Kurds - hardened PKK cadres. The PKK's insurgency began in 1984 with armed ambushes against security forces, chosen to illustrate the futility of the state in protecting its own. ${ }^{35}$ By 1990, Turkey had imprisoned tens of thousands of Kurdish men suspected of participating in acts of sedition. ${ }^{36}$ This was at the peak of the hostilities between the state and the Kurds, and by 1999 the Turkish government had evicted 3,500 villages, leaving over three million people homeless. ${ }^{37}$ In order to deny the PKK shelter and support, the state pursued a scorched earth policy, burning villages and causing the displacement of Kurds into cities. ${ }^{38}$ Kurdish women increasingly became the primary income earners for their families and the principal interlocutors with Turkish officials responsible for the detention of their male relatives. ${ }^{39}$ These factors empowered and politicized Kurdish women. ${ }^{40}$

The conflict between the Turkish state and the Kurds led PKK militants across the border to Syria from the late 1970s onwards. In Syria, the PKK was able to operate until 1998 protected within the framework of Cold War politics, in which the United States and the Soviet Union served, respectively, as guarantors of Turkish and Syrian security. For the Syrian government, the PKK was

tion against Kurdish Citizens in Syria, report for the 12th session of the UN Human Rights Council (2009) <http://lib.ohchr.org/HRBodies/UPR/Documents/session12/SY/ KIS-KurdsinSyria-eng.pdf>.

35 McDowall, A Modern History of the Kurds, 419.

36 Aliza Marcus, Blood and Belief: The PKK and the Kurdish Fight for Independence (New York: NYU University Press, 2007), 173 .

37 McDowall, A Modern History of the Kurds, 440.

38 Hugh Poulton, "Turkey", in Middle East Contemporary Survey 1995, Volume xIx, ed. Bruce Maddy Weitzman (Colorado: Westview Press, 1995), 654. McDowall cites Medico International and the Kurdish Human Rights Project when noting that the population of Diyarbakir, in south-east Turkey, grew from 380,00o in 1991 to 1.3 million in 1996. McDowall, A Modern History of the Kurds, 440.

39 Marcus, Blood and Belief, 173.

40 Gunter, Out of Nowhere, 31. 
a bargaining chip against the Turkish state's control of the water flowing from the Euphrates River into Syria. ${ }^{41}$ Scholars argue that there was, at this time, a tacit agreement between the Syrian government and the Kurds by which the sanctuary given the PKK in Syria served to "keep a lid on Syrian Kurdish unrest." 42 Nonetheless, it was in these years that relations between the Syrian Kurds and the PKK were cemented. After almost two decades of support, the PKK's sanctuary in Syria ended when the Syrian government, under the threat of war from Turkey, ousted the movement in 1998 from Syria. Öcalan was eventually caught in February 1999 in Nairobi and imprisoned on the island of Imrali near Istanbul. This opened a new chapter in the PKK's history, as Öcalan spent the following years developing the principles of democratic confederalism / democratic autonomy that were to redefine the PKK's ideology and place women at the centre of its ideological renewal.

\section{The Arab Uprisings Bring Opportunity for Syrian Kurdish Aspirations}

After Öcalan was expelled from Syria in 1998, remaining clandestine Syrian PKK cells formed the Democratic Union Party (Partiya Yekitiya Demokrat, PYD) in 2003. Events in the region, such as the fall of Saddam Hussein in 2003 and the rising influence of the Kurdistan Regional Government in northern Iraq, a region which had become autonomous in the early 1990s, served as an inspiration for Syrian Kurds. A year later, the outbreak of rioting at a football match in the ethnically mixed city of al-Qāmishlī / Qamişlo - now known as Rojava led to violent confrontations between Arabs and Kurds. The Syrian state responded with force, killing over a hundred Kurds. Thousands fled to northern Iraq. The atmosphere of repression created fertile ground for the growth of Kurdish dissatisfaction. In the following years, women actively engaged in political work. Hanife Hisên, a member of the Democratic Society Movement (TEV-DEM) leadership explains that between 2004 and 2012 "only women could function politically. [...] They organized at grass roots, did educational work and held congresses. The men who organized would get arrested, so the orga-

41 In particular, as the Southeast Anatolian Project (Güney Anadolu Projesi (GAP)) - a massive dam development harnessing rivers north of Syria - was finalized, Syria used the PKK as a bargaining chip to obtain a better annual water quota. Gunter, Out of Nowhere, 40. 
nizing work fell to the women." ${ }^{43}$ The outbreak of the Syrian conflict in March 2011 and the regional upheavals that followed brought unprecedented opportunities for the Kurds, both regionally and internationally.

Given their treatment at the hands of the regime, Syrian Kurds were part of the uprising from the outset. Confronted with the prospect of several enemy fronts, the Assad government sought to placate the Kurds by granting them citizenship rights and by retreating from Kurdish areas. ${ }^{44}$ The assumption was that the Kurds were inadequately equipped to challenge the government and that they would, in any case, be held in check by the various local armed factions and, after 2014, by Daesh in particular. ${ }^{45}$ In 2012, when Syrian government forces withdrew from Kurdish-inhabited areas in northern Syria, control was handed to Kurdish militias. Later in November 2013, the PYD announced an interim government, divided along the three non-contiguous autonomous areas, or cantons, in the region of Rojava (also referred to as Western Kurdistan), including the Cizîrê (al-Jazīra), Kobanî, and Efrînê (Afrīn) cantons.

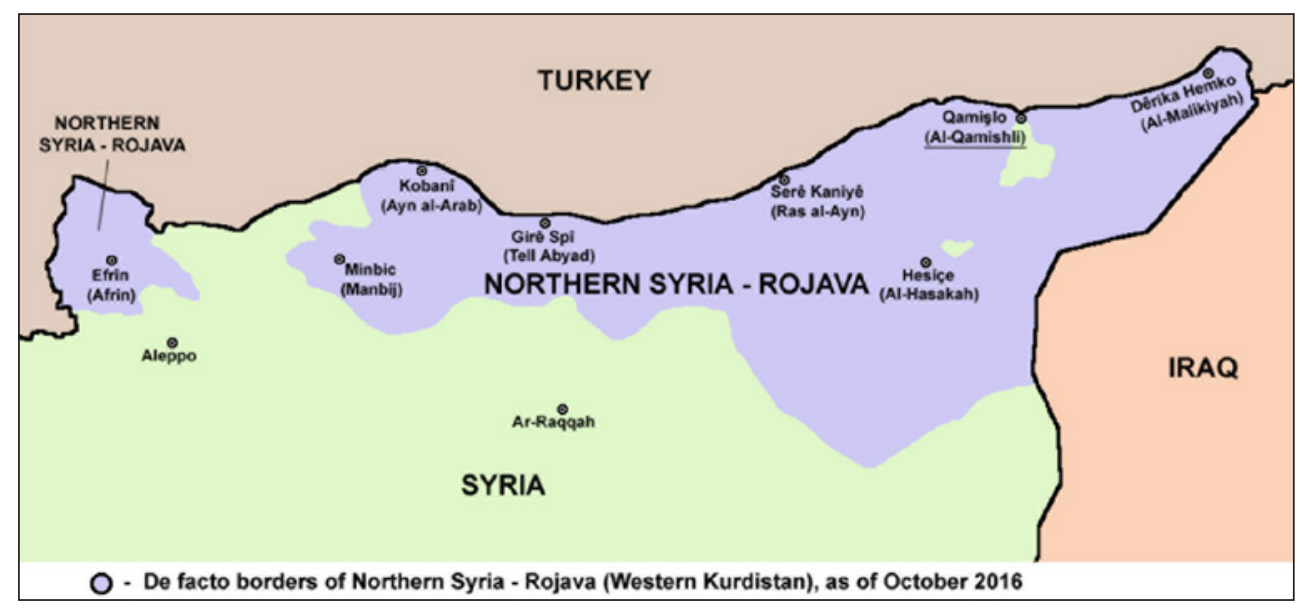

43 Hisên, quoted in Michael Knapp, Anja Flach, and Ercan Ayboga, Revolution in Rojava: Democratic Autonomy and Women's Liberation in Syrian Kurdistan (London: Pluto Press, 2016), 63 .

44 Can Cemgil and Clemens Hoffmann, “The 'Rojava Revolution' in Syrian Kurdistan: A Model of Development for the Middle East?”, IDs Bulletin, 47, no.3 (2016), 53-76, doi:10. 19088/1968-2016.144.

Ibid., 6 o. 
On 17 March 2016, the de facto administration of Rojava declared the founding of a federal system of government referred to as the Federation of Northern Syria - Rojava (abbreviated as NSR). ${ }^{46}$

\section{The Recruitment of Kurdish Women to the PKK}

Although the female combatants of the YPJ stole the headlines in 2014, women had already been active in the PKK since the 1990s. On 8 March 1995, the first women's congress took place, and by 1999 the PKK had a separate women's wing. ${ }^{47}$ In the early 1990 , by some estimates, women made up a third of the fighting force of 17,000 militants in the PKK. ${ }^{48}$ They were engaged both in support activities and in active combat. Of the 20 suicide bombings in Turkey between 1996 and 2011, the majority (11) were undertaken by women. Turkish sociologist Dogu Ergil contends that the disproportionate number of women used by the rebel group for suicide attacks was evidence of Kurdish women's exploitation by male compatriots, reinforcing the victim narrative. The argument follows that women were more expendable than men to the Ркк. ${ }^{49}$

Women's agency is also absent in the analysis of recruitment provided by PKK scholar Nihat Ali Özcan. According to him, the initial decision to enlist women resulted from the practical need to grow as an organization and the shortage of recruitment in the earlier years of the PKK. ${ }^{50}$ Women and girls were recruited from a wide cross section of society - from rural areas to urban centres and from university students to diaspora communities.

In the early years of the movement, families "gave" girls to the movement, and later, as the myth of the Kurdish freedom fighter grew, many young women left home to join the PKK, at a moment when female agency became more salient. The Youth Council of Kurdistan (YCK), established in October 1987, organized systematic recruitment campaigns, increasing its activities in the 1990s in high schools and universities, both abroad and in Turkey. According to Alkan,

46 For the map, see Wikimedia Commons <https://commons.wikimedia.org/wiki/File:Nor thern_Syria_-_Rojava_october_2016.png>.

Melis, "Beyond Female Soldiers: The Feminism of Rojava", Alternatives International Journal, 2 March 2016 <http://www.alterinter.org/spip.php?article4447>.

48 Nihat Ali Özcan, "Ркк Recruitment of Female Operatives", Terrorism Focus 4, no.28 (2007) $<$ http://www.jamestown.org/single/?no_cache=1\&tx_ttnews[tt_news]=4394>.

49 V.G. Julie Rajan, Women Suicide Bombers: Narratives of Violence (New York: Routledge, 2011); and Dogu Ergil, "Suicide Terrorism in Turkey: The Workers' Party of Kurdistan", in Countering Suicide Terrorism: An International Conference (Herzliya: The International Policy Institute for Counter-Terrorism, 2001), 105-28. Özcan, op.cit, "РКк Recruitment of Female Operatives". 
"many young people who lived their first revolution experience under YCK later joined the organisation's mountain cadres." 51

The recruitment of women also served as a tactical measure, according to Özcan, who argues that Öcalan regarded women's emancipation as a tool to destroy the structures of feudal Kurdish society. ${ }^{52}$ Breaking down the established patriarchal social order would allow for the emergence of a new society in which women would take part equally. In Özcan's analysis, the PKK chief recognized that feudal family and tribal structures presented an obstacle to recruitment: Kurds in south-east Turkey preferred the security provided by family and tribe. Women were at the bottom of a tribal hierarchy based on adherence to a strict patriarchal system. Advancing women's liberation weakened traditional structures and replaced them with the party organization. ${ }^{53}$ Once dissolved, the unit of the "family" could be recreated within the liberation movement.

\section{Assigning Agency: The Motivations of Female Fighters}

In this case study of Kurdish female combatants, women's motivations for joining militant movements resonate with the larger-n case study conducted by Jacques and Taylor. ${ }^{54}$ Using coding methodology and drawing on existing literature on female combatants of diverse militant organizations, Jacques and Taylor examine 54 cases, grouping them into five main categories of motivation: (a) Social, (b) Personal, (c) Idealistic, (d) Key Event, and (e) Revenge, then noting the frequency with which they are mentioned in the literature. ${ }^{55}$ Distinguishing between the categories is challenging because motivations are not exclusive, but the exercise is nonetheless valuable for its ability to illustrate the range of female agency. The first category ("Social") encompasses motivations such as gender equality, education and career prospects, humiliation and repression, and family. It is the most significant motivational category, with 34 mentions in Jacques and Taylor's surveyed literature. The "Personal" category,

$5^{1} \quad$ Necati Alkan, "Youth and Terrorism: Example of РКк", in Political Violence, Organized Crime, Terrorism, and Youth, ed. M. Demet Ulusoy (Washington, DC: Ios Press, 2008), 15969,163 .

$5^{2}$ Interview, N.O. Özcan, 13 October 2002, Ankara.

53 Özcan, op.cit., "Ркк Recruitment of Female Operatives".

54 Karen Jacques and Paul J. Taylor, "Female Terrorism: A Review", Terrorism and Political Violence 21, no.3 (2009), 499-515, doi:10.1080/09546550902984042.

55 The text is presented in table form in ibid., 506. 
the second most frequently noted, is mentioned 18 times in the literature and focuses more narrowly on personal issues such as monetary concerns, personal suffering, or feelings of exclusion from a social group. In the "Idealistic" category, with a frequency of mentions at 15 , motivations include religion, nationalism, commitment to a cause, and martyrdom. Finally, in the "Key Event" category - mentioned 12 times - the focus is on a singular instance, such as the loss of a loved one, displacement, a humiliation, or some other negative, uncontrollable event. At the very bottom is the "Revenge" category, with only 4 mentions.

As noted above, motivations often coexist and reinforce one another, as is evident from the following statement by YPJ commander Jiyan Afrin, in which social motivations (gender equality/repression/family issues) combine with those of idealism (nationalism/commitment to a cause): "Our struggle is not just to defend our land. We as women, take part in all walks of life, whether fighting against ISIs or combating discrimination and violence against women. We are trying to mobilize and be the authors of our own liberation." 56 Jacques and Taylor's categorizations are expedient as a tool for illustrating the variations in Kurdish women's agency depicted in the table below using similar motivational categories that combine with one another. In particular, the "Social" category reinforces all other motivational categories.

Motivational category

Social/Key Event

Social/ Key Event/Revenge

Social/Idealistic

Social/Personal

Social/Idealistic/Key Event

Social/Idealistic

\section{Motivation}

Forced migration from rural areas to urban centres

in Turkey - poverty, breakdown of patriarchal

structures

Family's role (girls to avenge members killed)

High social status attained in community by joining movement

In rural areas to avoid marriage at young age to older men, agrarian work, childbearing. Emancipatory.

In diaspora communities, motivation related to forced migration and issues of integration in host community.

National liberation (intricately linked to feminism)

$5^{6}$ Dirik, op. cit., "The Women's Revolution in Rojava”. 
In the case of the Kurdish female fighters in Syria, it is the final category of liberation, given its centrality in the ideology of the Kurdish movement, that deserves closer examination.

\section{“The Revolution Is Female"}

Öcalan's thoughts on the role of women spring from the PKK's original leftist (Marxist-Leninist) ideology. ${ }^{57}$ In a piece from 2010 entitled "The Revolution Is Female", he begins by stating: "No social group has ever been exploited physically and psychologically to the same extent as women". In his analysis, the oppression of women begins with the rise of the class society: it is capitalism that has "turned her into merchandise to be offered up for sale on the market." Gender oppression is seen as the cornerstone of capitalism, so to defeat capitalism, one must do away with established gender structures. In his words, "It was slavery of women throughout society that paved the way for all other forms of hierarchy and state structures". The institution of family was "one of the most important building blocks" of the capitalist system. ${ }^{58}$ Öcalan's analysis clearly derives from the writings of Friedrich Engels (d. 1884), in particular his views on marriage as an oppressive tool in the civilizational stage of human development; thus women can only be liberated if they are brought back into public industry through the abolition of the monogamous family structure. ${ }^{59}$ The PKK leader's approach is ideological - to dissolve the family, which he sees as a "micro-model of the state" conceived by men. ${ }^{60}$ For Öcalan, the nationstate embodies patriarchal oppression: "Capitalism and nation-state denote the most institutionalized dominant male. More boldly and openly spoken:

57 By Öcalan's own admission, his thoughts on gender equality are also influenced by his complex relationship to Kesire Yildirm, a fellow militant and his wife from 1974 to 1987 . He elaborates on this in his prison writings. Abdullah Öcalan, Prison Writings: The PKK and the Kurdish Question in the 21st Century (London and Cologne: Transmedia Books, 2011), Chapter 8.

$5^{8}$ This critique of class and gender relations draws inspiration from Friedrich Engels and his thoughts on the origin of the family, private property, and the state. See Alex De Jong, "Stalinist Caterpillar or Libertarian Butterfly: The Evolving Ideology of the РКк", Europe Solidaire Sans Frontières (ESSF), 15 March 2015 <http://www.europe-solidaire.org/spip. php?article34511>.

59 Friedrich Engels, The Origin of the Family, Private Property, and the State, Marx/Engels Selected Works, Volume Three, (Marx/Engels internet archive, 1884) <https://www.marx ists.org/archive/marx/works/1884/origin-family/>. Chapter II, Part 4 "The Monogamous Family"

6o All quotes in this paragraph from Öcalan, op. cit. "The Revolution Is Female”. 
capitalism and nation-state are the monopolism of the despotic and exploitative male."61 Öcalan's explicit link between capitalism and gender bring the question of women's emancipation to the core of the Kurdish project for a new society, thus recruiting women to the cause. Significantly, while there were those in the PKK who opposed Öcalan's conversion from Marxist-Leninism after 2005, the female leadership supported him. ${ }^{62}$ Öcalan was thus aware that they could serve as an important power base. In sum, while Öcalan's ideological approach differs from Özcan's instrumentalist analysis above, the end result - the need to draw women into the movement - remains the same.

Until the 1990s, women were engaged with the Kurdish movement based on the goal of Kurdish nationhood. After Öcalan's capture in 1999, the aims of the movement shifted towards the concept of "democratic autonomy" or "democratic confederalism", inspired by the work of American anarchist and libertarian socialist Murray Bookchin (with whom Öcalan exchanged letters from 2004 onwards, although the two never met). ${ }^{63}$ Bookchin sought to redefine the notion of citizenship through the project of confederalism, explained as "a network of administrative councils whose members or delegates are elected from popular face-to-face democratic assemblies, in the various villages, towns, and even neighborhoods of large cities." 64 The centrality of the state diminishes, and the social contract which forms the basis of the relationship between the state and the citizen is replaced by direct democracy. Thus when Turkish politicians speak of the essentialist threat of the Kurdish state, it is at one level a misconception of the Kurdish movement's ideological objectives, which are to weaken the unit of the state and replace it with the primacy of the political unit of the community and its organic, networked system of governance. ${ }^{65}$

61 Abdullah Öcalan, Liberating Life: Woman's Revolution (Cologne: International Initiative "Freedom for Abdullah Öcalan - Peace in Kurdistan", 2013) <http://www.freeocalan.org/ wp-content/uploads/2014/o6/liberating-Lifefinal.pdf., 43>.

62 Wes Enzinna, "A Dream of a Secular Utopia in Isis Backyard", The New York Times Magazine online, 24 November 2015 < https://www.nytimes.com/2015/11/29/magazine/adream-of-utopia-in-hell.html>.

63 Although the ideological shift from national independence to local autonomy within Turkey is most clearly articulated after the capture of Öcalan, Leezenberg notes that changes were already underway in the 1990s in an effort to gain the support of other ethnic and sectarian groups such as Alevis and Christians. Leezenberg, "The ambiguities of democratic autonomy", 674 .

64 Murray Bookchin, “The Meaning of Confederalism”, Green Perspectives: A Left Green Publication 20 (November 1989) <http://dwardmac.pitzer.edu/Anarchist_Archives/bookchin/ gp/perspectives2o.html>.

65 Leezenberg points out that the most important ideological shift occurs already in the late 1990s with the move away from a nationalist project to autonomy within Turkey. This intellectual development continues with the addition of the discourse of Mesopotamian 
Unsurprisingly, this holds considerable appeal to Kurds, for whom state power in Turkey, Syria, and Iraq has been tantamount to oppression. It is through the project of autonomy - that is, for example, "when placing local farms, factories, and other enterprises in local municipal hands" or "when a community [...] begins to manage its own economic resources in an interlinked way with other communities"66 - that confederalism can be achieved. Five principles guide the concept of democratic confederalism: the right to selfdetermination, non-statist communitarian democracy, grassroots participation, "higher level" decision-making as merely implementation of low level decisions, and anti-nationalism. ${ }^{67}$ Discussions of democratic confederalism had already begun at party congresses in the 1990s and 200os, after Öcalan, like his mentor Bookchin, had become disenchanted with the orthodox traditions of Marxist-Leninist party organization. ${ }^{68}$ The concept of radical democracy adopted by the PKK after Öcalan's imprisonment eventually opened up a greater space for women's political participation through the bottom-up creation of a new vision for society.

With this, the idea of the grand revolution faded, to be replaced by greater emphasis on grassroots feminism, everyday politics, and encouraging change within society from below. ${ }^{69}$ It was a development that Akkaya, Jongerden, and Simsek describe as transforming the movement from rebellion to reconstruction..$^{70}$ According to gender scholar Acik, it was women who supported Öcalan following his incarceration and his controversial political and ideological shift after $1999 \cdot{ }^{71}$ Öcalan returned their confidence by making gender liberation a pillar of his new ideology.

multiculturalism and pre-political communitarian 'organic society', inspired by Bookchin. See Leezenberg, "The ambiguities of democratic autonomy", 673 .

66 Bookchin, op. cit., "The Meaning of Confederalism".

67 House Organ, "Rojava”, Capitalism Nature Socialism 26, no.1 (2015), 1-15. This publication also has a good critical assessment of democratic confederalism as put into practice.

68 Nazan Üstündağ, "Self-Defense as a Revolutionary Practice in Rojava, or How to Unmake the State", The South Atlantic Quarterly 115, no.1 (2016), 197-210, doi:10.1215/003828763425024 .

69 Necla Acik, "Kobane: The Struggle of Kurdish Women against Islamic State", Open Democracy, 22 October 2014 <https://www.opendemocracy.net/arab-awakening/necla-acik/ kobane-struggle-of-kurdish-women-against-islamic-state> .

70 Ahmet Hamdi Akkaya, Joost Jongerden, and Bahar Simsek, eds. Isyandan InsayaKürdistan Özgürlük Hareketi [Kurdistan Liberation Movement from Rebellion to Construction] (Istanbul: Dipnot, 2015), as cited in Cemgil and Hoffmann, op. cit. "The 'Rojava Revolution' in Syrian Kurdistan", 54.

Acik, op.cit. "Kobane". 


\section{The Rojava Revolution: Feminism in Action}

Even before the Arab Uprisings, the contribution of Kurdish women in armed resistance and ideology formation broke taboos and redefined gender relations among the Kurds. ${ }^{72}$ The emphasis on women's liberation and grassroots demands for more power has yielded tangible results in the Rojava region. As a result of the adoption of a Social Contract Charter in Rojava, all decisions are made through people's houses, which comprise 15-30 people who deliberate, and, where practically possible, use consensus to resolve issues around, for example, energy, food distribution, and social problems, including sexual violence and domestic conflict. ${ }^{73}$ Most importantly, a minimum of 40 per cent of decision-making participants on all administrative levels have to be women (in practice).${ }^{74}$ This commitment is also reflected at higher levels. For example, the PYD has a male and female co-chair in all institutions, organizations, and associations - including medical, educational, military, and police councils. ${ }^{75}$ This model has also been put into practice in the pro-Kurdish People's Democracy Party (HDP) in Turkey, where women candidates made up 40 per cent of the political positions in the party during the 2015 national elections. Following the HDP's short-lived election victory, a record number of women were admitted into parliament. ${ }^{76}$ In addition, since self-declared autonomy, Kurdish women have established a dozen women's unions, associations, and committees that have conducted widespread gender awareness campaigns in all three cantons of the Rojava region.

The women's movement Yêtkiya Star is responsible for social and political mobilization so that even in a conflict, legislation has been passed to "criminalize forced marriages, domestic violence, honor killings, polygamy, child

\footnotetext{
72 Ibid.

73 Ibid., 2.

74 The Charter can be found at <http://peaceinkurdistancampaign.com/resources/rojava/ charter-of-the-social-contract/>.

75 Rosa Benathan, “Guns, Widows \& What you don't hear about in Syria: An Interview with Margaret Owen", Bad Housekeeping: Writing a new generation of gender (online magazine), 17 January $2014<$ http://web.archive.org/web/20140130022319> <http://www.badhousekeeping.com/2014/o1/17/guns-widows-what-you-dont-hear-about-syria-an-interviewwith-margaret-owen/>.

76 However, the inability to form a coalition government nullified the election results, leading to a new election, in which the HDP lost votes and the number of women MPs declined dramatically. See "Turkey set for Parliament with highest woman representation ever", Hurriyet Daily News, 8 June 2015 <http://www.hurriyetdailynews.com/Default.aspx?pageI $\mathrm{D}=238 \& \mathrm{nID}=83659$ \&NewsCatID $=339>$.
} 
marriage and bride price."77 This has given Kurdish women under PYD rule a political voice and attracted fighters to the cause. As explained by the sixteenyear-old YPJ fighter Barkhodan Kochar, "The war influenced me a lot. Before joining the YPJ, whenever I asked my family about politics, they'd say, 'That's not your business, you're just a girl.' But when I saw how the women of YPJ gave their lives for what they believed in, I knew I wanted to be one of them."78 Twenty-year-old YPJ fighter Aljan Denis adds, "Where I am now, men and women are equal and we all have the same thought, which is fighting for our ideology and the rights of women."79 However, the idealism that has allowed them the opportunity to mould an alternative future flourishes in an unstable geopolitical context.

\section{The Geopolitics of Rojava}

At the time of writing (June 2017), the Rojava region remains part of Syria. However, the long-term outcome of the Syrian civil war is far from settled. The region's future depends to a large extent on the fallout of ongoing political negotiations, which encompass claims raised by Kurdish fighters, including female combatants.

As reflected in the media interest, one of the greatest boosts to the Kurdish female combatants' engagement has been the rise of Daesh and Kurdish resistance to its efforts to establish itself in northern Iraq and Syria. But even from the start of the Syrian revolution, the YPG/YPJ, with military training and support from the PKK, has defended Kurdish areas. Nonetheless, since 2012, the contrast between the religiously conservative Daesh and the Kurdish female combatants has been instrumental in building awareness around the phenomenon of Kurdish women combatants' active engagement. ${ }^{80}$ Viewed through the lens of gender, the conflict between the YPJ and Daesh has been presented as a "civilizational battle", and the media discussion of Kurdish female fighters has thus been presented primarily as a battle of resistance to conservative norms. ${ }^{81}$

77 Dirik, op. cit. “The Women's Revolution in Rojava”.

78 Interviewed in Newsha Tavakolian, "Meet the Women Taking the Battle to IsIs", Time Magazine, 2 April $2015<$ http://time.com/3767133/meet-the-women-taking-the-battle-toisis/. (The quote is taken from subtext picture 8 of $16>$.)

79 Ibid. (The quote is taken from subtext picture 4 of 16 .)

80 The commander of the YPG's female forces, Asya Abdullah, was even invited to meet President Hollande of France, despite its being known that France's NATO ally Turkey was hostile towards the movement. See Gökhan Bacik, "Turkey and Russia's Proxy War and the Kurds", The German Marshall Fund of the United States, January 2016 <http://www.gmfus. org/publications/turkey-and-russias-proxy-war-and-kurds>.

81 The women foreign fighters joining Daesh present a challenge to the understanding of 
The role of Kurdish female fighters received particular attention during the siege of Kobanî that began on 15 September 2014. As with Kirkuk in Iraq, Kobanî in Syria is symbolically important. As Sirwan Kajjo, a Syrian Kurdish analyst, has noted, "Kobane symbolises the Kurdish resistance, not only in Syria but in other parts of the Middle East. Its loss would translate into a defeat for the entire Kurdish nation." ${ }^{82}$ The Kurds' success in defending their own enclaves raised fears in Turkey that a contiguous zone on its border (connecting Kobanî and Efrînê cantons) would develop. Although the battle for Kobanî was a key moment in Daesh's decline, it was equally a turning point in the TurkishKurdish relationship, resulting in Kurdish recognition that, for the Turkish government, they were the greater threat. ${ }^{83}$ Importantly, the Kurdish victory also strengthened the Kurdish cause in the eyes of the international public. ${ }^{84}$ By contrast, Turkey's late commitment to the fight against Daesh cost the lives of its Turkish and Kurdish citizens and destabilized the country domestically. Partly as a result, between 2015 and 2016, more than four hundred people died due to terror attacks in Turkey. ${ }^{85}$

Daesh as a jihadist terror group. Thus, the narrative around IsIs female combatants is understood in terms of victimhood, with the press diminishing the agency of female fighters by referring to them instead as "jihadi brides" or misled "schoolgirls". See Jon Henley and Vikram Dodd, "Kadiza Sultana: London Schoolgirl who joined Isis believed killed in Syria airstrike", Guardian, 12 August 2016 <https://www.theguardian.com/uk-news/ 2016/aug/11/london-schoolgirl-kadiza-sultana-who-joined-isis-believed-killed-in-syriaairstrike> and Lori Hinnant, "Jihadi bride who fled Syria uses life on probation as lesson", Associated Press, 8 October 2016 < http://bigstory.ap.org/article/2321c55c130842fcb90176o9 $8 \mathrm{fa} 2755^{2} /$ jihadi-bride-who-fled-syria-uses-life-probation-lesson $>$. For a discussion of IsIS and gender issues, see also the contribution of Brynjar Lia, "The Jihadi Movement and Rebel Governance: A Reassertion of a Patriarchal Order?" in this Special Issue.

82 Tanya Goudsouzian, “Kobane explained: What's so special about it?", Al Jazeera, 21 October 2014 <http://www.aljazeera.com/news/middleeast/2014/10/kobane-explained-whatso-special-about-it-201410216033364111.html>.

83 Max Fisher, "Turkey's twin terrorist threats explained", The New York Times, 29 June 2016 $<$ https://www.nytimes.com/2016/06/30/world/middleeast/turkeys-twin-terroristthreats-explained.html?_r=0 $>$.

84 Bacik, "Turkey and Russia's Proxy War and the Kurds", The German Marshall Fund of the United States, January 2016 <http://www.gmfus.org/publications/turkey-and-russiasproxy-war-and-kurds, $2>$.

85 "New Year's Attack on Turkey comes amid wave of violence", The New York Times, 1 January 2017 <http://www.nytimes.com/interactive/2016/o6/28/world/middleeast/turkey-terrorattacks-bombings.html?_r=0 $>$. 
Another Kurdish victory, in the strategic border town of Tal Abyad in June 2015, resulted in a reversal of Turkish policy regarding intervention in Syria. ${ }^{86}$ Previously, the AKP government had maintained that military intervention in the conflict would be a breach of Syrian sovereignty. However, when the PYD and allied rebel groups - with Us air support - were victorious in Tel Abyad, they were able to merge two Kurdish enclaves along the Turkish border - Kobanî Canton in the west and Cizîrê (al-Jazîra) Canton in the east, the latter covering much of al-Hasakah governorate by late 2016. Turkish fears that the Kurds would make further territorial gains resulted in the Turkish parliament granting the government authority in October 2015 to intervene militarily in Iraq and Syria.

In the same month, the YPG/YPJ partnered with other regional militias fighting Daesh to establish the Syrian Democratic Front (SDF, Quwwāt Sūriyā alDìmuqrāțìa), a multi-ethnic and multireligious alliance. Channelling weapons and ammunition to this umbrella organization was, in part, an attempt by the United States to placate Turkish antagonism over the Us-Kurdish relationship and prevent tensions between Arabs and Kurds. ${ }^{87}$ However, the group also represented a challenge to the National Coalition for Syrian Revolutionary and Opposition Forces - supported by Turkey, Qatar, and Saudi Arabia - which had previously excluded the Kurds, Arabs, and Christians. Although the majority of the SDF forces were from the YPG/YPJ, a growing number - 40 per cent by March 2016 - were from other ethnic groups and presented an alternative secular grouping potentially capable of acting as a unifying force. ${ }^{88}$ Threatened by the ever-present spectre of Kurdish unity, Turkey launched Operation Euphrates Shield in August 2016 with the explicit aim of distancing Daesh from the Turkish border, and with the implicit goal of preventing the Rojava Kurds, who had crossed west of the Euphrates River, from connecting with Efrînê Canton. ${ }^{89}$

86 Sinan Ekim and Kemal Kirişci, "Turkey's Unending Dilemma in Syria: Will it intervene?", Brookings blog, 2 July 2015 <https://www.brookings.edu/blog/order-from-chaos/2015/o7/ 02/turkeys-unending-dilemma-in-syria-will-it-intervene/>.

87 Liz Sly, "Us Military Aid is fueling big ambitions for Syria's Leftist Kurdish Militia", Washington Post, 7 January 2017 <https://www.washingtonpost.com/world/middle_east/ us-military-aid-is-fueling-big-ambitions-for-syrias-leftist-kurdish-militia/2017/01/o7/ 6e457866-c79f-11e6-acda-59924caa2450_story.html?utm_term=.96fea7bcf $42 \mathrm{e}>$.

88 "Syrian-Kurdish SDF successfully absorbing non-Kurdish groups, says us", Rudaw, 9 March 2016 <http://rudaw.net/english/middleeast/syria/ogo320161>.

89 The intervention had cost the Turkish military 40 soldiers by the end of 2016. By comparison, Russian losses from 30 September 2015 until December 2016 numbered 23 soldiers (out of 4,00o troops on the ground). Fehim Taştekin, "Would Putin accept Turkish Buffer Zone in Syria", Al-Monitor: Turkey Pulse, 26 December 2016 <http://www.al-monitor.com/ 
The future of the Rojava revolution will be indelibly formed by the political outcome that eventually emerges from the Syrian war. Despite the efforts of the Kurds against Daesh, Assad stated in October 2016 that the federalist project promoted by the Northern Syria Rojava (NSR) administration not only lacked the support of the Kurds but also was unrealistic in areas of Arab majority. ${ }^{90}$ Following the recapture of rebel-held Aleppo in October 2016, a Russian-mediated meeting on the future of Rojava was held in Erbil on 28 October between the government and the two dominant Kurdish factions in Rojava..$^{91}$ Earlier meetings had concluded with the Russian delegation arguing for a federal system in order to avoid Syria's partition. However, the strengthened position of the Assad government after its victory in Aleppo altered the power dynamic, with Assad promising support for the Kurds if they back him in upcoming elections, relinquish the idea of a federal system, and return under government control. ${ }^{92}$ Significantly, the PYD removed the word 'Rojava' from the official name, a concession to the region's multi-ethnic make-up, announcing its new name as the Democratic Federal System of Northern Syria.

\section{Conclusion}

Regardless of the outcome of the Rojava experiment and the inevitable gaps between ideals and reality as Öcalan's ideology is tested on the ground, the engagement of Kurdish men and women in the process is shifting traditional understandings of gender in Kurdish society. Not least, there is an awareness that revolutionary gains may be lost once the revolution subsides, as has been the case in other Middle Eastern countries in which women played a significant role during the Arab Uprisings. As Sebahat Tüncel, from the HDP, notes,

pulse/originals/2016/12/turkey-euphrates-shield-operation-syria-russia-putin-buffer. html\#ixzz4UssNfW5G $>$.

9o Zara Salih, a Member of the Kurdish Yekiti Party in Syria noted: "Assad keeps sending messages to the Kurds, especially to the Democratic Union Party, saying that what they're doing against IsIS is their duty and there are no privileges for them." Cited in "Assad: Syrian Kurds don't want federalism", ARA News, 15 October $2016<$ http://aranews. net/2016/10/syrias-assad-reiterates-kurds-no-right-federalism/>.

These are the "Democratic Society Movement" (also known as "Movement for a Democratic Society", TEV-DEM) and the "Kurdish National Council in Syria". The former is primarily dominated by the PYD and the latter is supported by Iraqi Kurdistan's president, Masoud Barzani, and the Iraqi KDP.

92 "Syria: Kurds and Damascus meet over tensions, future of Rojava", Rûdaw, 29 October 2016 $<$ http://rudaw.net/english/middleeast/syria/29122016?keyword=Rojava $>$. 
"Women in politics try to transform society so that we can prevent any kind of reverse movement that would send women back home."93 As a consequence, Kurdish female fighters' struggle against patriarchy and state oppression defines the Rojava experiment as a dual threat against the AKP's conservative values, such as familial policies where women are envisaged primarily as caregivers and homemakers.

In sum, while the reasons noted above for Kurdish women joining the YPJ may indeed be based on individual experiences of gender oppression or collective experiences of ethnic persecution, or both, there needs to be a space for women's engagement beyond these two narratives of resistance to oppression. The idea of building a society in which gender equality is a bearing foundation strengthens the resolve of Kurdish women in their fight against Daesh by giving them a stake in an egalitarian future in which they play an integral political part. This perspective is markedly different from considering their engagement through the lens of gender victimhood or resistance alone. Their agency is best expressed in the words of Sozda, a YPJ commander in Amûde: "We don't want the world to know us because of our guns, but because of our ideas. We are not just women fighting IsIs. We struggle to change the society's mentality and show the world what women are capable of." 94

The Kurdish female commander's words summarize three points that have been addressed in this article. First, fighting for territorial autonomy in the Rojava region is an internal objective but is also played out to an international audience. The world is watching, and female fighters appeal to external supporters in their struggle. Second, the struggle for Kurdish national liberation is underpinned by a strategic ideological shift. Violent resistance alone is not sufficient to obtain terrorial autonomy: ideas such as freedom, equality, and grassroots participation are as important as armed struggle. Third, and most important, Öcalan's statement in 2010, in which he emphasized that the Kurdish people's freedom is inseparably bound to women's freedom, was quickly heeded by Kurdish women. This statement emphasized a core tenet in the reinvention of the PKK's ideology: the understanding that freedom can only be achieved through the defeat of the patriarchal system. As shown in this article, PKK women and their sister organization, the YPJ, represent the embodiment of this new ideology. Partly facilitated by the events of the 2011 Arab Uprisings and the ensuing Syrian civil war, Öcalan's rearticulation of gender relations as

93 Jenna Krajeski, “Kurdistan's Female Fighters", Atlantic online, 30 January $2013<\mathrm{https}$ :// www.theatlantic.com/international/archive/2013/o1/kurdistans-female-fighters/272677'> 
part of national liberation resonated in the hearts, minds, and actions of Kurdish female fighters. ${ }^{95}$

95 The author wishes to thank the researchers at the Centre for Islamic and Middle East Studies at the University of Oslo, particularly Rania Maktabi and Brynjar Lia, for their extensive comments to earlier versions of the article. Parts of this article stem from findings from: Pinar Tank, "Kurdish Women: Liberation through the Barrel of a Gun?" (Oslo: Department of Culture Studies and Oriental Languages (IKOS), University of Oslo, Report 2015-2016), also presented at the 2015 British Society of Middle Eastern Studies Annual Conference. 